\title{
The Nature of Virtue and the Need for Self-Knowledge in Plutarch's Demosthenes-Cicero
}

\author{
JEFFREY BENEKER
}

The first three chapters of Plutarch's Demosthenes comprise a prologue that introduces the Demosthenes-Cicero pair. Plutarch begins this prologue with a chreia that raises an ethical question about the right environment for happiness and the development of virtue. Referring to himself in the first person and addressing his dedicatee, Sosius Senecio, by name, he engages his reader directly, first about happiness and virtue, and then about his approach to the Lives that appear in this book and his reasons for pairing them. In the process, he provides personal information about himself, remarking on his fondness for his hometown and his late start in learning Latin. These remarks are typically taken at face value, and have become central to Plutarch's own biography in modern times ${ }^{1}$. Indeed, the prologue as a whole has been read most carefully not for understanding Plutarch's ethics or method in the Demosthenes-Cicero, but to characterize the form and function of his prologues in general ${ }^{2}$. It is also important, however, to consider the prologue's immediate context and its bearing on the book that it introduces. In fact, two central themes of the prologue that virtue is independent of environment and that self-knowledge is critical to success - are important themes in the Lives that follow. In this essay I present a reading of the prologue that demonstrates how closely connected it is to the contents of the book and how its themes are elaborated in the pair of Lives.

An important comparandum for the opening of the DemosthenesCicero is the prologue to the Alexander-Caesar, where Plutarch asks his readers not to quibble if he does not narrate all the great deeds of his heroes. In defense of his omissions, he makes his oft-quoted claim that he "is not writing histories, but lives" (Alex. I,2). Often read as a general methodological statement applying to the composition of all the Parallel

\footnotetext{
1 See e.g. Barrow (I967) 37; Jones (I97I) 20; Lamberton (200I) 20.

2 See Stadter (1988); Duff (2008) and (2014).
} 
Lives, in addition to being important evidence for the generic distinction between biography and historiography in antiquity, this claim also - and perhaps primarily - applies to the particular problem of the AlexanderCaesar. That is, Plutarch was grappling with an abundance of material about two figures who loomed large in Greek and Roman conceptions of the past and whose accomplishments were already well known to his readers. As he states in the continuation of the prologue, however, Plutarch was not striving for completeness. Rather, he was intent on relating the accomplishments and anecdotes that revealed his subjects' character, regardless of their historical significance ${ }^{3}$.

The prologue to the Demosthenes-Cicero similarly warns the reader about material that will not be encountered in the Lives that follow, though before turning to that problem Plutarch focuses on an ethical question. He begins with a chreia from an encomium of Alcibiades, in which the author states that "the first thing required for happiness is 'the

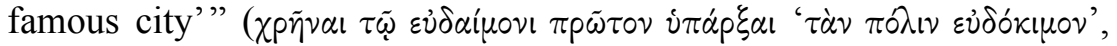
Dem. I,I). Plutarch counters with an emphatic and concise argument that true happiness in fact "depends mostly on one's character and

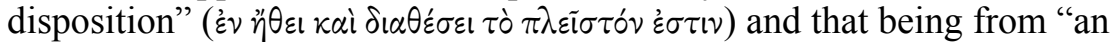
inglorious and humble homeland" is no more a barrier to happiness than from being born of "an ugly and small mother" $(\mathrm{I}, \mathrm{I})$. As he refutes the necessity of the glorious city, Plutarch, we may note, expects his reader to agree without argument that one may be happy regardless of the stature or form of one's mother. That point established, he shifts the discussion more pointedly to virtue, on which (assuming further agreement from his reader) happiness depends. Virtue, he claims, can take root anywhere and is thus the responsibility of the individual. "And so if we in some way fail to think and live as we ought," he writes, "we will attribute that rightly to ourselves rather than to the smallness of our homeland" (I,4). Employing the first person plural, Plutarch thus involves his dedicatee (and the reader in general) in a dialogue about the nature of happiness and virtue.

His aim in this opening paragraph is partly rhetorical, and in that sense it represents a typical method for introducing a book. At the outset, he must capture his readers' attention and gain their good will as he draws them into the narrative that follows ${ }^{4}$. At the same time, however, he subtly clarifies the criteria by which he will evaluate the subjects of this particular book. Demosthenes and Cicero were leading political figures in the most glorious of cities in Plutarch's world, Athens and Rome, and so the fame of these cities might have colored a retelling of their

\footnotetext{
${ }^{3}$ See further Duff (I999a) I5; Pelling (2006) 266.

${ }^{4}$ Cf. Stadter (I988) 284; Duff (20I4) 340-34I.
} 
Lives $^{5}$. That is, a reader beginning this book might casually assume that the two men were worthy of study because of where they had lived and the important historical events in which they had been involved. With this initial discussion, however, Plutarch separates the virtue of the statesman from the reputation of his city, thus setting the stage for an investigation of Demosthenes and Cicero as individuals, rather than as an Athenian and a Roman. His aim, he states later in the prologue, is to compare their "natures and dispositions" through the lens "of their accomplishments

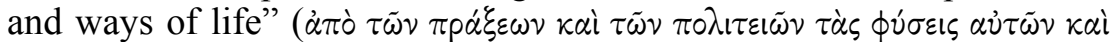

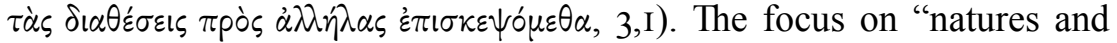
dispositions" at the conclusion of the proem recalls, albeit inexactly, the "character and disposition" from the more general discussion of true happiness and virtue in the opening, and so, considered as a whole, the prologue prepares the reader to expect an examination of the individual qualities of the two men.

In the prologue's middle chapter, Plutarch redirects his theme slightly to introduce the real disadvantage of the small city: for one who undertakes to write a history based on readings that are foreign and from widely dispersed sources, "in reality the first requirement is especially 'that

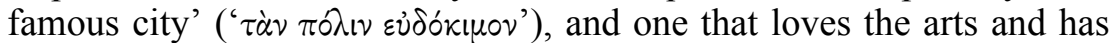
a large population" $(2, \mathrm{I})^{6}$. A large, famous city provides access to books and orally transmitted stories not available elsewhere, Plutarch goes on to explain. "But I live in a small city," he adds, "and am fond of living there so that it does not become smaller" $(2,2)$. As Plutarch particularizes his discussion, inserting a relatively rare autobiographical detail and bringing to the fore his home in Chaeronea, he is making two points that influence our reading of the Lives that follow. First, this discussion performs a function similar to the claim that Plutarch makes in the Alexander-Caesar in that it explains why information known to the reader and perhaps considered essential to a narrative of the subjects' lives will not appear in these biographies. This is especially true for the details of Cicero's life,

\footnotetext{
${ }^{5}$ Plutarch does not emphasize that Cicero was born in Arpinum, a small but not undistinguished city - it was also the birthplace of Gaius Marius - outside Rome, although he does include two pieces of information that link Cicero to Arpinum. He includes an account of Cicero's ancestry that has him descended on his father's side from the Volscian 'king' Tullus Attius (Cic. I,2), but Plutarch does not mention that Arpinum was an important Volscian center. Rather, he seems more interested in the royal connection; see Moles (1988) I47. He also reports that Cicero possessed an estate at Arpi $(8,3)$, which is probably a mistake for Arpinum; see Moles (1988) I58. In general, however, Plutarch emphasizes Cicero's career in Rome.

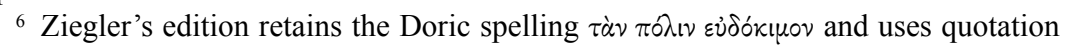
marks to make the reference back to Dem. I, I explicit. I have tried to capture that reference in my translation, "that famous city".
} 
which Sosius and other Roman readers would have known well but which could have been difficult for Plutarch to research thoroughly. Plutarch in fact seems to be referring mainly to Cicero when he mentions "foreign" and "widely dispersed" sources, and (as we shall see below) he returns to the question of reading Cicero's works in the balance of the chapter.

Second, in mentioning his home Plutarch continues with the subtle elaboration of his ethical program. After arguing that virtue and true happiness depend on personal attributes - character, nature, and disposition rather than the glory of one's home city or the status of one's mother, he then reminds his dedicatee that he himself is from a small place and, moreover, feels no shame. If we accept his argument, then we also concede that Plutarch has leveled the playing field. By emphasizing virtue's connection to the individual, he opens the lessons of the book, and the ethical program of the Parallel Lives in general, to readers from a variety of backgrounds. This seems an especially important point to make in a work dedicated to a man such as Sosius, who served as quaestor in Achaea in the late 8 os CE (where he likely met Plutarch), held the offices of tribune and praetor under Domitian, and was consul twice (in 99 and I07) under Trajan ${ }^{7}$. Sosius might rightly identify with Cicero, who in addition to earning his fame as orator and statesman was Sosius' predecessor along the cursus honorum at Rome. Plutarch, however, is uncoupling virtue and status so as to promote an ethical program focused on the individual, which might not only help a man like Sosius to separate his glory from his character, but which could also apply to readers beyond the dedicatee, who would not all have had the chance to be Roman or Athenian citizens or to hold high office.

This point may also be significant for its appearance in the Demosthenes-Cicero, which Plutarch tells us is the fifth book in his series of Parallel Lives (3,I). The book that was probably first, EpaminondasScipio, is lost, and Plutarch does not tell us which books he wrote second through fourth in the series. Based on internal evidence, however, four books are likely contenders for those three positions: Cimon-Lucullus and Pelopidas-Marcellus are most likely in that group, with either SertoriusEumenes or Philopoemen-Flamininus making the third ${ }^{8}$. Of these books, three have prologues (Cim.-Luc., Pel.-Marc., Sert.-Eum.), but none of them addresses Sosius by name or focuses the discussion so narrowly on the question of personal virtue. It may be that in the Demosthenes-Cicero,

${ }^{7}$ On the offices and dates for Sosius Senecio's career, see Jones (I970) IOI-I02. It is not certain when the Demosthenes-Cicero was published, but the Parallel Lives as a whole were probably begun after $96 \mathrm{CE}$, and perhaps dedicated to Sosius in celebration of his consulship in 99; see Jones (I966) 70.

8 Jones (1966). 
Plutarch is for the first time in the series addressing his readership directly about their own progress in virtue, arguing explicitly that great men from the past may be judged according to their personal qualities, and implying that all men - the famous and the relatively obscure - participate in the same ethical system. This universality is assumed in prologues to some of the later books, such as the Demetrius-Antony, where Plutarch discusses the value of negative examples (Demetr. I), and the AemiliusTimoleon, where Plutarch writes that his Lives highlight virtue and allow both his readers and himself to order their own lives according to the exempla furnished by great men of the past (Aem. I,I-2). In these and other prologues, Plutarch encourages his readers to engage in personal reflection and self-improvement, and the overall program of the Lives seems to assume this sort of critical (and self-critical) reader as well ${ }^{9}$. In the prologue to the Demosthenes-Cicero, however, we find Plutarch engaging the reader on this issue for the first time.

The relationship between birth and happiness is important for the program of the Lives, but the discussion in the prologue establishes a concept that is important to this particular book as well. Both Demosthenes and Cicero eventually ascend to powerful positions in their glorious cities, but Plutarch is careful to show that their ascent depended on their personal qualities. Plutarch, in fact, names this as one of the facts that makes their careers parallel ${ }^{10}$, and in the opening chapters of both Lives, he takes up questions about the statesmen's origins and ancestry. In the proemial opening of the Demosthenes proper, Plutarch writes that Demosthenes' father was of a good Athenian family, but he also repeats the accusation of Aeschines that his maternal grandmother was a barbarian, though he says he cannot verify the claim (Dem. 4,I-2). In fact, Aeschines in his speech Against Ctesiphon had accused Demosthenes' grandfather of "disregarding the city's laws" (Ctes. I72) in marrying a Scythian woman, by which he meant that he had violated Pericles' law requiring both parents to be citizens of Athens for their child also to be a citizen ${ }^{11}$. According to Aeschines' charge, Demosthenes' mother was not born an Athenian citizen, and so neither was Demosthenes. Aeschines, in fact, asserted that he was not even a Greek, let alone an Athenian, disparaging him as "a barbarian who speaks Greek" because of his ancestry. Plutarch might not have expected his readers to recall these details, but at least, as we saw above, he expected them to accept without argument that a man may be

\footnotetext{
9 See Duff (20II).

10 "For I do not think two other orators could be found who, coming from inglorious and small beginnings, became powerful and great" (Dem. 3,4)

11 There is doubt whether the law was in effect when Demosthenes' mother was born; see Lintott (2013) 49.
} 
happy even though born of "an ugly and small mother" (I,I) and so discount Aeschines' charge. In the prologue, city and mother were conflated: both could be small (in size, stature, or significance), but their diminutive status posed no barrier to their offspring's progress in virtue. The trajectory of Demosthenes' career is similarly unimpeded by his problematic lineage, and he goes on to overcome other obstacles (the fraud of his guardians, his weaknesses as a speaker) as he trains himself to be a leading orator and politician at Athens.

In the second Life of the pair, family is similarly an important factor for Cicero. In this instance, however, his mother is reported "both to have

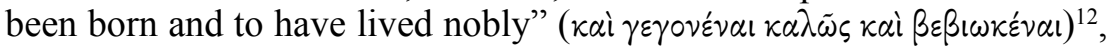
but his father is obscure, perhaps notorious, and Cicero himself might have been raised in a fuller's shop (Cic. I,I-2). Having dealt with parentage briefly, Plutarch devotes most of the proemial opening to Cicero's cognomen 'chick pea', which invited mockery. When he was launching his political career, his friends thought he should change the name, but he reveled in it, claiming that he would "strive to make the name 'Cicero' more glorious than the name of Scaurus and Catulus" $(\mathrm{I}, 5)$. The theme has developed from the first Life to the second, but the essential characteristic of advancement through personal achievement rather than inherited reputation remains constant.

The prologue's initial focus on the relationship between origins and virtue is thus developed as a theme for both Lives. An even stronger thematic connection exists for the balance of the prologue. After declaring his pride in humble Chaeronea, Plutarch explains that he learned Latin late and not well enough to appreciate the subtleties of Roman style. He is pleased with what he knows, but proper practice and exercise in the language eluded him (Dem. 2,2-4). Offering another biographical detail, this passage is typically taken at face value, and in the context of the proem it further supports Plutarch's assertion that many potential sources in Latin were beyond his reach. Plutarch returns to his knowledge of Latin as the prologue concludes, to explain why he will report his subjects' personal qualities (the "natures and dispositions" quoted above) but will not attempt to examine their speeches or pronounce which was the more pleasing or skilful orator $(3, \mathrm{I})^{13}$. In doing so, he reinforces an important $4, \mathrm{I})$

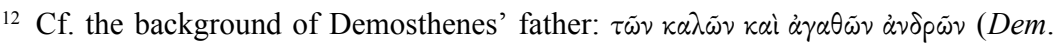

13 Stadter (1988) 286, is typical in reading Plutarch's statements about himself as primarily autobiographical: "The Demosthenes notes the difficulty of working in Chaeronea, away from the libraries and learned conversation of a city like Athens, at a time when Plutarch needed to collect passages drawn from scattered foreign writers. Moreover, his knowledge of Latin is insufficient to attempt the kind of literary comparison which might be expected in a book on Demosthenes and Cicero (Dem. 2)." 
topic of the proem - preparing readers to accept what is missing from the book - while at the same establishing another theme that will be essential to both of the Lives that follow: one ought not to attempt feats beyond the limits of his skill and experience.

In recusing himself from an analysis of his subjects' speeches, Plutarch quotes Ion of Chios, who wrote that "the might of the dolphin is

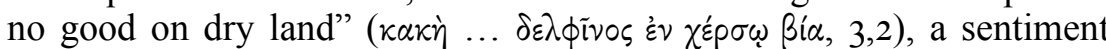
he says was ignored by Caecilius of Caleacte, who went beyond his depth in attempting to compare Demosthenes and Cicero as orators. The recollection of Caecilius prompts Plutarch to mention the Delphic maxim, "Know thyself" ( $\left.\gamma \nu \tilde{\omega} \theta, \sigma \alpha v \tau \tau^{\prime} \nu\right)$, something that he claims must be difficult to accomplish, otherwise it would not be a bit of wisdom attributed to a god. Having asserted self-knowledge as a virtue for an author, however, he also seeks the same quality in his heroes, treating the DemosthenesCicero in part as an extended study of how a knowledge of one's own limits is critical to a politician's success. In this regard, the heroes serve as negative examples. Demosthenes, in the first Life, is a gifted speaker and a talented politician, but he lacks courage. Even so, he assumes a leading role in the movement to oppose Philip of Macedon, a policy that requires him to demonstrate fearlessness and daring. Demosthenes appears to forget himself, however, and as his career progresses, he shows himself to be (in the modern version of the metaphor) a fish out of water. Plutarch builds to a demonstration of Demosthenes' failure through an extended comparison with Pericles, whom he uses to establish the depth that lies beyond Demosthenes' abilities. The comparison is systematic, and marks both the beginning and the beginning of the end of Demosthenes' career.

In the first part of the Life (chapters 5-II), Plutarch describes Demosthenes as an orator, in the second part he narrates his career in politics. In the first part, once the young Demosthenes decides to pursue public speaking as his vocation, he quickly becomes disheartened when he is not well received by his fellow citizens. Plutarch at this point introduces two characters who vividly call out his weaknesses. First Eunomus:

Finally, Eunomus the Thriasian, by this time a very old man, saw him after he had separated himself from the demos and was wandering despondently in the Piraeus, and he rebuked him, saying that, although his oratory was very much like that of Pericles, he was betraying himself through cowardice and softness ( $\left(\pi^{\prime} \dot{\alpha} \tau 0 \lambda \mu i^{\prime} \alpha \varsigma^{\prime} \kappa \alpha i \mu \alpha \lambda \alpha \kappa^{\prime} \alpha \varsigma\right.$ ) because he was neither confronting the crowds courageously ( $\varepsilon \dot{\nu} \theta \alpha \rho \sigma \tilde{\omega} \varsigma)$ nor training his body for debates, but he was neglecting it as it wasted away through luxurious living $(6,5)$.

Plutarch reports Eunomus' rebuke, but allows Demosthenes no response. Instead, he immediately introduces the actor Satyrus, who demonstrates 
to Demosthenes the weakness of his delivery. He asks the budding orator to recite a passage from tragedy, then recites the same passage himself, imbuing it with such "a fitting character and disposition" ( $\dot{\varepsilon} \nu$

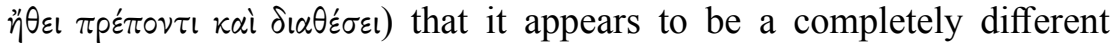
passage than the one Demosthenes performed (7,I-4). In this instance, Plutarch does narrate Demosthenes' reaction: "Convinced of how much adornment and grace are added to a speech by one's delivery, he believed that practice was worth little or nothing to someone who neglected the pronunciation and disposition of the words being spoken" $(7,5)$. A desire to impress the public and a conviction that showmanship was critical to his success drove Demosthenes to toil at perfecting his delivery, so much so that he earned a reputation as a practiced orator who would not speak extemporaneously (Dem. 8). Thus he follows the example of the actor Satyrus, treating public speaking as a rehearsed performance, and ignores the counsel of Eunomus to train himself to be courageous in the face of opposition. His critics, however, like Eunomus, observed his timidity: "This they took as a sign of his cowardice in moments of

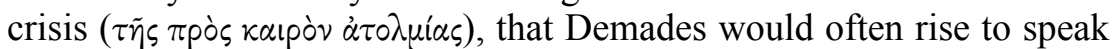
spontaneously when the crowd was shouting down Demosthenes, but Demosthenes would never do that for him" $(8,7)$. In Plutarch's narrative, Demosthenes lacks a characteristic that is essential to a great statesman, and he fails to remedy the problem even in the face of public criticism.

Plutarch is so committed to casting his Demosthenes as timid that he must respond to reports that contradict this image. He takes this up in chapter 9 by citing a series of counterexamples, in which Demosthenes is said to have shown boldness and spoken extemporaneously. How could these examples exist? he asks rhetorically. His answer is two-fold, and once again depends on a comparison to Pericles:

But the man appears to have believed that most of the characteristics of Pericles were not relevant for him, but emulating and imitating his style, his demeanor, and his practice of not speaking spontaneously or on every matter that presented itself, as though Pericles had become great from these practices, he did not at all cultivate his reputation in crises, nor was he very often willing to make his efficacy depend on fortune. However, the speeches he delivered contained more courage

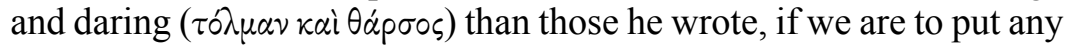
stock in Eratosthenes, Demetrius of Phalerum, and the comic poets $(9,2-3)$.

The point here is that Demosthenes avoided speaking extemporaneously as often as he could, and did not like to involve himself in situations where he could not control the terms of debate. Nonetheless, his impromptu delivery demonstrated more courage and daring than his writ- 
ten speeches. But "more courage and daring" is not "courage and daring" per se, and in fact the examples that Plutarch includes in the balance of the chapter show Demosthenes not so much brave as erratic: Eratos-

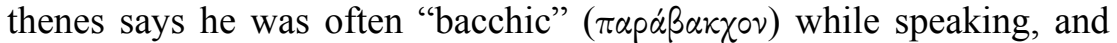
Demetrius claims that he once swore an oath to the demos "as though inspired" ( $\check{\sigma} \sigma \pi \varepsilon p \dot{\varepsilon} \nu \theta 0 v \sigma i \tilde{\omega} \nu \tau \alpha)$, presumably at the moment of speaking. And none of this matters anyway, since Plutarch transitions from this topic by dismissing the impact of whatever courage Demosthenes did display: "Even so, everyone agrees that Demades, employing his natural talent, was invincible and when extemporizing surpassed Demosthenes' careful preparations" (IO,I). Plutarch goes on to show that he was surpassed by yet another contemporary politician, Phocion (IO,3-5).

In this account of Demosthenes' oratory, Plutarch reveals two particular weaknesses, one of courage and the other of performance. Demosthenes was made aware of both, but overcame only one. Perhaps he misunderstood Eunomus' lesson and believed that he was in fact imitating Pericles, as Plutarch seems to hint in 9,2, quoted above. Plutarch concludes his discussion of Demosthenes as orator more positively, with several anecdotes that demonstrate his wit. After this he refocuses the reader's attention on his thesis from the prologue: "Although I have still more to say about these and other humorous sayings, I shall pause here; it is right to observe the rest of his manner and character from his accom-

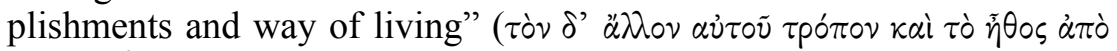

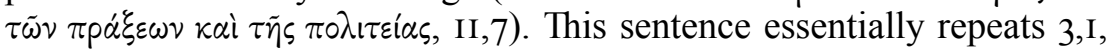
where Plutarch writes, as we saw above, that he would explore his subjects' "natures and dispositions through their accomplishments and way

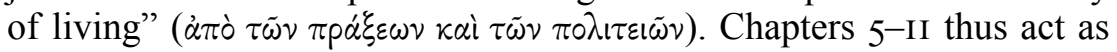
an extended study of Demosthenes as orator, while his political career begins with chapter $\mathrm{I} 2$.

The two parts are not entirely separate, however. Demosthenes enters politics as Philip of Macedon begins to press Greece militarily, and uses his oratorical skills in a staunch defense of the Greek cause. In this way, he "quickly acquired a reputation and was raised to a position of admiration by his speeches and straight talk" (I2,7). Plutarch defends Demosthenes against critics who charge him with political inconsistency, clearly admiring his opposition to Philip and defense of Greece, but nonetheless he does not allow the reader to forget who Demosthenes really was:

Panaetius the philosopher says that most of his speeches - for example, On the Crown, Against Aristocrates, On the Immunities, the Philippics - were thus written on the supposition that only what is of itself good should be selected for its own sake. In all of these speeches he guides his fellow citizens not towards what is most pleasant, easy, 
or profitable, but in many instances he thinks that one's safety and salvation ought to be placed second to what is good and proper, so that if he had had a warrior's bravery ( $\dot{\alpha} \nu \delta \rho \varepsilon i \alpha \pi \circ \lambda \varepsilon \mu \iota \sigma \tau \eta \dot{p}(\circ \varsigma)$ and acted on every occasion from pure motives in addition to the ambition found in his arguments and the nobility of his speeches, he would have been worthily included not in the ranks of orators, with the likes of Moerocles, Polyeuctus, and Hyperides, but at a higher level with Cimon, Thucydides, and Pericles (13,5-6).

There is no doubting Demosthenes' oratorical skill, his high ideals, or his commitment to the cause of Greek freedom. This Plutarch reinforces through further examples in chapter I4, even mentioning a very Periclean ability to speak frankly to the demos and oppose its desires ( $\pi$ pòs $\tau \dot{\alpha} s$ $\dot{\varepsilon} \pi \imath \theta \nu \mu i \alpha \varsigma \tau \tilde{\omega} \nu \pi \circ \lambda \lambda \tilde{\omega} \nu \dot{\alpha} \nu \tau \iota \tau \varepsilon i v \omega \nu, \mathrm{I} 4,3)^{14}$. But the divide marked by Eunomus and Satyrus still exists as Demosthenes ascends to the height of his political influence in Athens. Pericles remains a consistent presence in the narrative, to show what Demosthenes might have been and the sort of leader that Athens needed at this time. It was not the case that men like Pericles no longer existed, for in the very next sentence Plutarch writes that Demosthenes' contemporary Phocion, though advocating an

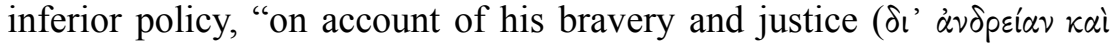
$\delta(\kappa \alpha 10 \sigma \dot{v} \eta \eta)$ was considered to be a man who was nowise inferior to Ephialtes, Aristides, and Cimon" (I4,I). Cimon appears on both lists, which together establish these great fifth-century statesmen (three of whom have biographies in the Parallel Lives) as the standard by which Plutarch measures Demosthenes and his fourth-century contemporaries.

As Philip continues to threaten, Demosthenes becomes more aggressive. He advocates an invasion of Euboea, the sending of a force to Byzantium, and a league against Philip (I7), and eventually he becomes the leader of the Athenian and Theban resistance (I8). Many signs foretold the end of freedom for the Greeks, Plutarch says (I9), but Demosthenes, who himself invokes Pericles as a model, rejects these warnings:

But it is said that Demosthenes, confident in Greek arms and lifted to a joyous state by the strength and eagerness of so many men who were challenging their enemies, did not allow them to heed oracles or listen to prophecies, but suspected that even the Pythia was supporting Philip. And he invoked the memories of Epaminondas the Theban

${ }^{14}$ Cf. Per. 33,6, where Pericles refuses to call the demos to assembly, "fearing that

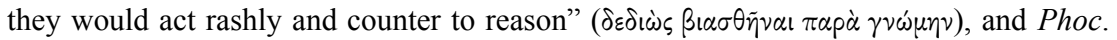
8,3 , where Plutarch says that Phocion "opposed the demos most of all, and never spoke

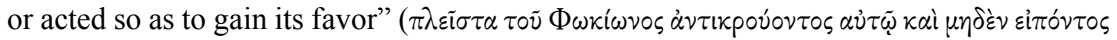

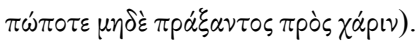


and Pericles the Athenian, recalling how those men believed all such things to be excuses for cowardice and instead relied on reasoned plans $(20, \mathrm{I})$.

There is great irony in Plutarch's characterization of events, for he has devoted much of the earlier chapters to documenting Demosthenes' timidity in comparison to the bravery of Pericles. The reader thus knows that Demosthenes is beyond his depth and, in tragic fashion, does not realize it. Or, to phrase things in terms of the prologue, as he leads the army to the fateful showdown with Philip at Chaeronea (Plutarch's 'small' hometown), he is a dolphin on dry land. Therefore, what happens next hardly comes as a surprise:

To this point he was a brave man (àvì $\dot{\alpha} \gamma \alpha \theta o ́ s)$. But in the battle he demonstrated no action that was honorable ( $\left.\kappa \alpha \lambda o^{\circ}\right)$ or that corresponded with his words, but he abandoned the formation, running away most shamefully and after casting off his arms ( $\tau \dot{\alpha}$ ö $\pi \lambda \alpha \dot{\rho}(\psi \alpha \varsigma)$ ), nor, as Pytheas said, did he feel any shame for the inscription on his shield, which was inscribed in golden letters: "With good fortune" $(20,2)$.

Demosthenes' flight from the battlefield at Chaeronea is vividly marked as cowardice through the casting away of his arms. Rhipsaspia, or 'shieldtossing', especially as portrayed in the poetic fragment by Archilochus (5 West), was in the ancient world a disgraceful and cowardly act ${ }^{15}$. Indeed, Plutarch records in his Apophthegmata Laconica that Archilochus was expelled from Sparta as soon as he arrived for having written "that

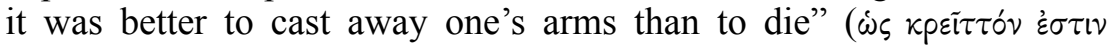

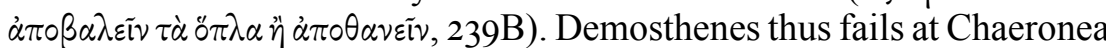
precisely because he lacked courage, an event that is entirely predictable in Plutarch's arrangement of the Life.

Even more important, however, is the lesson conveyed to the reader by this event, since it depends not so much on Demosthenes' role as a leading statesman at a pivotal moment in Greek history as it does on the nature of his mistake. That is to say, he attempted to act as though he were someone he was not. Eunomus had warned him of the need to be courageous using Pericles as his model, but Demosthenes either ignored the warning or failed to understand who Pericles really was. In this way, the lesson is decontextualized so that it might apply to any of Plutarch's readers. Despite the lengthy buildup to Chaeronea in the narrative of the Life and the charge of anti-heroic rhipsaspia, the lesson here is simply an

\footnotetext{
15 On the tradition see Smith (2015)
} 
amplification of the Delphic maxim from the prologue, 'Know thyself': Demosthenes extended himself beyond his abilities, and he failed.

There is more to the Life of Demosthenes following Chaeronea, which demonstrates that despite his cowardice in battle, his reputation and influence are not completely ruined. Even so, the lesson on selfknowledge is central, and it is reinforced in the second Life, though in the context of already having been well established in the first ${ }^{16}$. I will summarize briefly how Plutarch extends the theme to the Cicero with some modification. Delphi again asserts its influence, when Cicero enquires of the oracle how he might become "most famous" ( $\dot{v} \nu \delta \circ \xi$ ' $\tau \alpha \tau \circ \varsigma)$ and is told "to make his own nature rather than the opinion of the masses $(\tau \dot{\eta} \nu \tau \tilde{\omega} \nu \pi \circ \lambda \lambda \tilde{\omega} \nu \delta \delta \xi \alpha \nu)$ the guide of his life" $(5, \mathrm{I})$. At Rome the opinion of the masses is expressed through election and success as an advocate, and so Cicero, heeding the oracle's advice, refrains from seeking public office. As a result, he is overlooked $(5,2)$. But his nature in fact turns

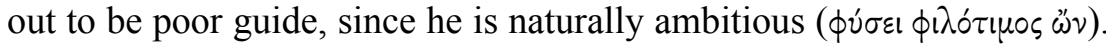
Succumbing to the urging of his father and friends, he gives himself over to pleading cases in court $(5,3)$. Here he rises quickly: "immediately he shone in reputation ( $\left(\dot{\xi} \xi \dot{\xi} \lambda \alpha \mu \psi \varepsilon \tau \tilde{\eta} \delta \delta \xi_{\eta}\right)$ and distinguished himself greatly among those competing in the forum" $(5,3)$. He next begins to seek public office, and from this point the Life documents his political ascent.

His public life will end in a precipitous fall, and Plutarch relies on the pattern established in the Demosthenes to explain the cause of Cicero's demise. Early in his career, when he returns from his quaestorship in Sicily and finds that no one in Rome has noticed his accomplishments, he is discouraged $(6,4)$. Then he has a change of heart:

But later he reasoned with himself and removed a great part of his ambition by believing that the glory ( $\tau \dot{\eta} \nu \delta o ́ \xi \alpha \nu)$ towards which he was striving was an infinite thing and had no reachable limit. Even so, his excessive pleasure at being praised and his extreme passion for glory

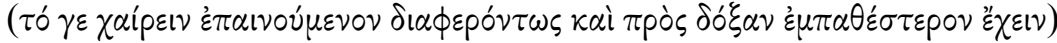
remained with him always and upset many of his correctly reasoned plans $(6,4-5)$.

Cicero in fact never reaches a limit but might wish that he had, for his relentless pursuit of glory leads directly to his demise. Late in his career, when Cicero is at the height of his influence, Octavian challenges Antony to become heir to Julius Caesar (45). After Octavian defeats Antony in battle at Mutina, the Senate distrusts him, and so he turns to

16 See Pelling (1986) 94 on Plutarch establishing a "normal pattern" in the first Life of a pair and exploiting it with "an interesting variation" in the second. 
Cicero for support. Knowing Cicero's desire for glory, expressed here as 'love of holding office' ( $\left.\phi i \lambda \alpha p x^{\prime} \alpha\right)$, he suggests that the two seek the consulship together $(45,6)$. "In this, however," Plutarch writes, "Cicero, an old man, was led on and tricked by a young man" (46,I). After gaining the consulship and the goodwill of the Senate, Octavian abandons Cicero, reconciles with Antony, and allows Cicero to be proscribed and murdered $(46,2-6)$.

As Demosthenes ignores Eunomus, so Cicero fails to heed the oracle's advice not to let glory (that is, others' opinion of him) be his guide. In their failures, both heroes are vexed by limits, though in different ways. Demosthenes commits himself to a situation that is beyond his ability, whereas Cicero believes that the glory available to him is unlimited and so makes it his lifelong pursuit. 'Know thyself' is thus re-interpreted to mean that one must know when to stop. For both Lives, however, the prologue sets the tone, with its focus on the virtue of the individual and the importance of self-knowledge. Even small details - the reference to Chaeronea and the wisdom of the god of Delphi - play important roles in the central lessons of the Lives, further demonstrating the cohesiveness of the prologue and the Lives that follow. The prologue to the DemosthenesCicero, then, is essential to this book because it establishes critical interpretive themes, and it connects this book to the aims of the Parallel Lives by directing the readers' attention to the character, nature, and disposition of famous statesmen. 